\title{
Impact of Fertilizer and Planting Geometery on Garlic (Allium sativum L.) Yield in Saline-Sodic Soil
}

\section{Muhammad Qaisar Nawaz ${ }^{1}$, Khalil Ahmed ${ }^{1 *}$, Ghulam Qadir ${ }^{1}$, Amar Iqbal Saqib ${ }^{1}$, Muhammad Rizwan ${ }^{1}$, Muhammad Faisal Nawaz ${ }^{1}$ and Imtiaz Ahmad Warraich ${ }^{2}$}

${ }^{1}$ Soil Salinity Research Institute (SSRI), Pindi Bhattian 52180, Pakistan; ${ }^{2}$ Citrus Research Institute Sargodha, Pakistan.

\begin{abstract}
The present research work was undertaken from 2013 to 2016 to evaluate the efficacy of different phosphorus $(\mathrm{P})$ rates and planting geometry for the successful garlic production under saline environment. The experimental design was split-plot with three repeats. Three planting geometry $(10 \mathrm{~cm} \mathrm{x} 20 \mathrm{~cm}, 15 \mathrm{~cm}$ x $20 \mathrm{~cm}$ and $20 \mathrm{~cm} \times 20 \mathrm{~cm}$ ) and four phosphorus levels i.e. (i) control (no phosphorus), (ii) $\mathrm{P}$ (60 $\mathrm{kg}$ ha 1) recommended dose (RD), (iii) $125 \% \mathrm{P}$ of $\mathrm{RD}\left(75 \mathrm{~kg} \mathrm{ha}{ }^{-1}\right)$ and (iv) $150 \% \mathrm{P}$ of $\mathrm{RD}\left(90 \mathrm{~kg} \mathrm{ha}{ }^{-1}\right)$ were used. Observations included were; plant height, bulb mass, bulb diameter, cloves bulb ${ }^{-1}$ and bulb yield. Data revealed that phosphorus@125\% of RD with planting geometry $15 \mathrm{~cm}$ x $20 \mathrm{~cm}$ recorded maximum yield and yield attributes with higher economic returns, therefor, under saline-sodic conditions it is proposed as a most cost-effective management practice for garlic cultivation.

Received | November 03, 2018; Accepted | August 25, 2020; Published | October 04, 2020

*Correspondence | Khalil Ahmed, Soil Salinity Research Institute (SSRI), Pindi Bhattian 52180, Pakistan; Email: khalilahmeduaf@gmail.com Citation | Nawaz, M.Q., K. Ahmed, G. Qadir, A.I. Saqib, M. Rizwan, M.F. Nawaz and I.A. Warraich. 2020. Impact of fertilizer and planting geometery on garlic (Allium sativum L.) yield in saline-sodic soil. Pakistan Journal of Agricultural Research, 33(4): 692-699.

DOI | http://dx.doi.org/10.17582/journal.pjar/2020/33.4.692.699

Keywords | Garlic, salinity, Planting geometry, Phosphorus fertilization, Cost-benefit
\end{abstract}

\section{Introduction}

$\mathrm{P}$ akistan lacks arable land resources and due to salinity problem 6.67 million hectares (Khan, 1998) further extension in the vegetable production area is limited. The increasing demand of vegetables for a rapidly growing population will be met only by improving the yield potential of crops and increasing crop productivity per unit area. This objective would be achieved only through economical, suitable, highly productive and environmentally favorable production technologies. A huge gap exists between actual and yield potential of existing crops. Some of the main reasons for this difference are inadequate supply of inputs, lack of comprehensive production technologies and non-judicious use of fertilizers (Sankaran et al., 2005). Rate of a fertilizer that produces most profitable economic yield at the minimal cost is considered as optimal dose of that fertilizer (Ananthi et al., 2010). For maximum yield potential, nutrient requirement also increases considerably (Castellanos et al., 2001), so it is imperative to reassess the fertilizers rate for sustainable crop productivity under a salinized environment.

Phosphorus is an indispensable macronutrient for sustaining plant growth. According to Alam et al. (2009) maximum yield potential of a crop cannot be achieved without supply of optimum dose of phosphorus. Phosphorus plays a critical role in plant root system, flowering, uniform grain filling, seed maturity, regulation of metabolic pathways, photosynthates and enzymatic activities (Bhattacharyya and Jain, 2000).

Salt-affected soils pose severe constraints associated December 2020 | Volume 33 | Issue 4 | Page 692 
with their deteriorated physical and chemical properties, poor infiltration rate, water and nutrient availability and consequently affect plant growth. Moderate salinity may increase the availability of $\mathrm{P}$, but high salinity decreases $\mathrm{P}$ availability (Dhanushkodi and Subrahmaniyan, 2012). Plants growing in saline conditions are usually subjected to ionic imbalance because different toxic nutrients are taken up in large quantity and in varying ionic ratio as compared to the plant growing in normal soil conditions. $\mathrm{Cl}^{-1}$ inhibits the uptake of $\mathrm{P}$ to plants under hyper salinized environment (Awad et al., 1990). So, there is a need to employ multiple approaches to manage the saltinduced stress field. Use of stress-resistant cultivars, planting methods, fertilizers application and soil amendments are some common practices to improve crop yield in salt-affected soils (Yusuf et al., 2008; Zhang and Rue, 2012).

To ensure the maximum yield potential of vegetable crops optimum spacing is necessary. According to Dayi (2008) the ideal plant spacing is that which provides enough space for each plant with uniform distribution of existing space. Wide spacing in garlic caused the low plant population and consequently crop production is reduced (Karaye and Yakubu, 2006).

Garlic (Allium sativum L.) is grown for domestic use and as a source of earnings to many peasants in many parts of the countries (Getachew and Asfaw, 2000). In Pakistan, its production was 1698.1 tons during 2011-12 with an area of 172.4 thousand hectares (GoP, 2012). From 2001 to 2010, Pakistan was among the top ten garlic importing countries of the world (Sobia et al., 2014). Production of garlic crop in country can be improved by increasing its yield per unit area via increasing the efficacy of existing technology or introducing new production technology. In our country, farmers hesitate to adopt new technology. Therefore, improvement in efficacy of existing production technology is the most suitable choice to enhance agriculture productivity. Previously few attempts have been made to explore the full yield potential of garlic in salt-affected soils.

A review of numerous investigations has revealed that yield of garlic can be remarkably increased if the appropriate planting geometry is adopted. Similarly, Naruka and Dhaka (2001) stated that increasing the row space had significant effect on yield of garlic crop. Kilgori et al. (2007) experimented with three planting dates (29 November, 13 and 17 December) and four planting spaces $(5,10,15,20 \mathrm{~cm})$ on two garlic varieties. They concluded that planting space of $10 \mathrm{~cm}$ in a combination of 29 Nov. and 13 Dec. produced the highest garlic bulb yield. Abubaker (2008) also revealed that with 20 and $30 \mathrm{~cm}$ spacing, highest yield of bean was divulged as compared to $10 \mathrm{~cm}$. Gebrehawaria (2007) stated a positive response of garlic to application of $\mathrm{P}$ and $\mathrm{N}$ fertilizers and recorded the maximum number of leaf with the supply of $\mathrm{N}$ (120 $\left.\mathrm{kg} \mathrm{ha}^{-1}\right)$ and $\mathrm{P}\left(60 \mathrm{~kg} \mathrm{ha}^{-1}\right)$. Hore et al. (2014) suggested that maximum garlic yield can be achieved when 125 $\mathrm{kg} \mathrm{P}_{2} \mathrm{O}_{5}$ ha $^{-1}$ is supplied with $150 \mathrm{~kg} \mathrm{~K} \mathrm{O}$ and $200 \mathrm{~kg}$ $\mathrm{N} \mathrm{ha}{ }^{-1}$. Mohammad and Arshadi (2012) stated that planting the garlic with $0.12 \times 0.20 \mathrm{~m}$ spacing on Nov. 21 , was a suitable recommendation for farming this crop in terms of cloves mass and economic yield.

Considering what has been discussed above, the present work was conducted in saline-sodic soil to explore the simultaneous effects of row spacing and four different doses of phosphorus on growth and yield attributes of garlic crop.

\section{Materials and Methods}

The present work was investigated from 2013 to 2016 at Soil Salinity Research Institute (SSRI), Pindi Bhattian, Hafizabad, to explore the effect of different planting geometry $(10 \mathrm{~cm} \times 20 \mathrm{~cm}, 15 \mathrm{~cm}$ $x 20 \mathrm{~cm}$ and $20 \mathrm{~cm} \times 20 \mathrm{~cm})$ and four phosphorus levels i.e. (i) control (no phosphorus), (ii) P (60 kg $\mathrm{ha}^{-1}$ ) recommended dose (RD), (iii) $125 \% \mathrm{P}$ of $\mathrm{RD}$ $\left(75 \mathrm{~kg} \mathrm{ha}^{-1}\right)$ and (iv) $150 \% \mathrm{P}$ of RD $\left(90 \mathrm{~kg} \mathrm{ha}^{-1}\right)$ on growth performance and yield components of garlic in salt-affected soil. Whereas, $\mathrm{N}$ and $\mathrm{K}$ were applied uniformly@125-60 kg ha ${ }^{-1}$ in all the treatments. A salt-affected field, $\mathrm{EC}_{\mathrm{e}}=4.50\left(\mathrm{dS} \mathrm{m}{ }^{-1}\right), \mathrm{pH}_{\mathrm{s}}=8.77$ and $\mathrm{SAR}=32.0$ was selected. The experimental design was split-plot keeping a sub-plot size of $4 \mathrm{~m} \times 6 \mathrm{~m}$ and three repeats. Planting geometry was allocated in main plots whereas, phosphorus doses in sub plots. Cloves of garlic cultivar (Lehsin Gulabi) were planted in $1^{\text {st }}$ week of November and all fertilizers were applied at the field preparation. Agronomical practices and plant protection measures were assumed uniformly in all the treatments. Agronomic attributes like plant height, leaves plant ${ }^{-1}$, bulb diameter $(\mathrm{cm})$, bulb mass (gm), cloves bulb ${ }^{-1}$ and bulb yield (t. ha $\left.{ }^{1}\right)$ were recorded. Collected data was subjected to analysis of variance according to Steel et al. (1997) to 
calculate the significant differences among treatments means LSD at 5\% probability level was employed using STATISTIX 8.1 package software. To evaluate the economic feasibility of planting geometry and phosphorus rates, an economic analysis was estimated (Shah et al., 2013).

\section{Results and Discussion}

\section{Plant height $(\mathrm{cm})$}

Plant height, showed a positive response with increasing phosphorus doses, P application @ 150\% of recommended dose produced the statistically $(\mathrm{P} \leq$ $0.05)$ maximum plant height $(76.1 \mathrm{~cm})$ significantly different by $125 \% \mathrm{P}$ of recommended dose $(74.0 \mathrm{~cm})$ and shortest plant height $(65.7 \mathrm{~cm})$ was divulged in control (Table 1). Planting geometry also significantly affected the plant height, $15 \mathrm{~cm} \times 20 \mathrm{~cm}$ recorded significantly greater plant height $(74.3 \mathrm{~cm})$ followed by $20 \mathrm{~cm} \times 20 \mathrm{~cm}(72.1 \mathrm{~cm})$ and lowest plant height $(66.9 \mathrm{~cm})$ was noted with plant spacing of $10 \mathrm{~cm} \mathrm{x}$ $20 \mathrm{~cm}$. The interaction of phosphorus doses and planting geometry was also significant, phosphorus @ $150 \%$ of RD with planting geometry of $15 \mathrm{~cm} \mathrm{x}$ $20 \mathrm{~cm}$ recorded maximum plant height of $(79.0 \mathrm{~cm})$ followed by planting geometry of $20 \mathrm{~cm} \times 20 \mathrm{~cm}$ with phosphorus@150\% of RD. According to Blackshaw et al. (2004) supplementation with phosphorus is one of the most essential input in crop production as it is structural component of phospholipids and phosphoproteins and performs a critical role in photosynthesis and cellular energy transfer (Sharif et al., 2014). More plant height with increasing levels of phosphorus (125 and $150 \%$ of $\mathrm{RD}$ ) may be accounted for the favorable effects of phosphorus under salt stress conditions. The positive response of phosphorus supply on growth parameters have also been stated by Khiriya et al. (2001). Whereas plant height of garlic crop planted at $15 \mathrm{~cm} \times 20 \mathrm{~cm}$ tends to established better with more plant height than those closely spaced in $10 \mathrm{~cm} \times 20 \mathrm{~cm}$, as widely spaced plants enjoy more favorable growth conditions with less competition for nutrients and can intercept more solar light, so produced more plant height. Hussen et al. (2014) also reported that row spacing significantly affected the plant height of garlic crop.

\section{No. of leaves plant ${ }^{-1}$}

A distinguished increased in the number of leaves plant $^{-1}$ was observed with increasing rates of $\mathrm{P}$ (Table 2). Planting geometry also exhibited a distinct effect and $15 \mathrm{~cm} \times 20 \mathrm{~cm}$ proved superior (9.6 leaves plant $\left.{ }^{-1}\right)$ than $20 \mathrm{~cm} \times 20 \mathrm{~cm}\left(9.0\right.$ leaves plant $\left.^{-1}\right)$ and planting geometry of $10 \mathrm{~cm} \times 20 \mathrm{~cm}$. The data also reflected that the greater number of leaves (9.7) were documented with $150 \% \mathrm{P}$ of $\mathrm{RD}$ while 9.44 leaves plant $^{-1}$ were produced by $125 \% \mathrm{P}$ of $\mathrm{RD}$ however, both the treatments were statistically alike and control recorded the minimum number of leaves (8.0). The interactive effect of $\mathrm{P}$ and planting geometry also had a substantial effect on the leaves production. Planting geometry of $15 \mathrm{~cm} \times 20 \mathrm{~cm}$ produced greater number of leaves $(10.6$ plant $^{-1}$ ) with phosphorus @ 150\% of RD followed by $125 \% \mathrm{P}$ of RD (10.3). The results of our study that the more leaves plant ${ }^{-1}$ in planting geometry of $15 \mathrm{~cm} \mathrm{x}$ $20 \mathrm{~cm}$ are correlated with previous outcomes of Bodnar (1998) they reported that garlic plants at wide space show more vegetative growth and produced more leaves. The positive effect of higher dose of phosphorus (P@125\% and 150\% of RD) on leaf number might be ascribed to the beneficial effects on plant growth as plants did not suffer severe competition for plants nutrients to such degree that can reduce plant growth. Our outcomes are inconsistent with findings of (Jat and Shaktawat, 2001) they concluded that higher level of $\mathrm{P}$ progressively effects the growth parameters of crop plants.

\begin{tabular}{|c|c|c|c|c|}
\hline \multirow[t]{2}{*}{ Phosphorus levels } & \multicolumn{3}{|c|}{ Planting geometry } & \multirow[t]{2}{*}{ Mean } \\
\hline & $\begin{array}{l}10 \mathrm{~cm} \mathrm{x} \\
20 \mathrm{~cm}\end{array}$ & $\begin{array}{l}15 \mathrm{~cm} \mathrm{x} \\
20 \mathrm{~cm}\end{array}$ & $\begin{array}{l}20 \mathrm{~cm} \mathrm{x} \\
20 \mathrm{~cm}\end{array}$ & \\
\hline Control & $62.0 \mathrm{~h}$ & $69.6 \mathrm{e}$ & $65.6 \mathrm{f}$ & $65.7 \mathrm{~d}$ \\
\hline Recommended dose & $63.6 \mathrm{~g}$ & $72.0 \mathrm{~d}$ & $70.3 \mathrm{e}$ & $68.6 \mathrm{c}$ \\
\hline $125 \% \mathrm{P}$ of $\mathrm{RD}$ & $70.0 \mathrm{e}$ & $76.6 \mathrm{bc}$ & $75.3 \mathrm{c}$ & $74.0 \mathrm{~b}$ \\
\hline $150 \% \mathrm{P}$ of $\mathrm{RD}$ & $72.0 \mathrm{~d}$ & $79.0 \mathrm{a}$ & $77.3 \mathrm{~b}$ & $76.1 \mathrm{a}$ \\
\hline Mean & $66.9 \mathrm{c}$ & $74.3 \mathrm{a}$ & $72.1 \mathrm{~b}$ & \\
\hline
\end{tabular}

LSD for planting geometry: 1.1015; LSD for phosphorus levels: 0.8470; LSD for interaction: 1.4671

Table 2: Interactive influence of phosphorus and planting geometry on leaves plant ${ }^{-1}$ of garlic.

\begin{tabular}{lllll} 
Phosphorus levels & \multicolumn{3}{c}{ Planting geometry } & Mean \\
& $10 \mathrm{~cm} \mathrm{x}$ & $\mathbf{1 5 c m ~ x ~}$ & $\mathbf{2 0 c m ~ x}$ & \\
& $20 \mathrm{~cm}$ & $\mathbf{2 0 c m}$ & $\mathbf{2 0 c m}$ & \\
Control & $7.6 \mathrm{~g}$ & $8.3 \mathrm{efg}$ & $8.0 \mathrm{fg}$ & $8.0 \mathrm{c}$ \\
Recommended dose & $8.6 \mathrm{def}$ & $9.3 \mathrm{~cd}$ & $9.0 \mathrm{cde}$ & $9.0 \mathrm{~b}$ \\
$125 \%$ P of RD & $8.6 \mathrm{def}$ & $10.3 \mathrm{ab}$ & $9.3 \mathrm{~cd}$ & $9.4 \mathrm{ab}$ \\
$150 \%$ P of RD & $9.0 \mathrm{cde}$ & $10.6 \mathrm{a}$ & $9.6 \mathrm{bc}$ & $9.7 \mathrm{a}$ \\
Mean & $8.5 \mathrm{c}$ & $9.6 \mathrm{a}$ & $9.0 \mathrm{~b}$ &
\end{tabular}

LSD for planting geometry: 0.4998; LSD for phosphorus levels: 0.4859; LSD for interaction: 0.8417 . 
Bulb diameter $(\mathrm{cm})$

Data regarding the bulb diameter revealed that planting geometry, phosphorus rates and their interaction significantly affected the bulb diameter (Table 3). The results exhibited that maximum bulb diameter of $3.76 \mathrm{~cm}$ was documented by $150 \% \mathrm{P}$ of $\mathrm{RD}$ and was non-significant with $125 \% \mathrm{P}$ of $\mathrm{RD}$ which produced bulb diameter of $3.6 \mathrm{~cm}$. Similarly planting geometry of $15 \mathrm{~cm} \times 20 \mathrm{~cm}$ recorded the maximum bulb diameter of $3.6 \mathrm{~cm}$. The interaction of planting geometry and phosphorus was also significant. Phosphorus @ 150\% of RD had a higher bulb diameter of $4.0 \mathrm{~cm}$ which was similar with $125 \% \mathrm{P}$ of $\mathrm{RD}$ giving $3.8 \mathrm{~cm}$ in planting geometry of $15 \mathrm{~cm} \times 20 \mathrm{~cm}$. Adequate phosphorus nutrition significantly influences physiological processes such as photosynthesis, cell division and flowering (Sharif et al., 2014). Better results with planting geometry of $15 \mathrm{~cm} \times 20 \mathrm{~cm}$ and phosphorus applied @ 125 and $150 \%$ of $\mathrm{RD}$ might be corelated to effective exploitation of plant nutrients and accessibility of adequate amount of light, water and more area available to roots for nutrients acquisition. Tuncurk (2011) also reported that fenugreek produces the highest yield with the row spacing of $30 \mathrm{~cm}$ and $\mathrm{P} @ 90 \mathrm{~kg} \mathrm{ha}^{-1}$.

Table 3: Interactive influence of phosphorus and planting geometry on bulb diameter (cm) of garlic.

\begin{tabular}{|c|c|c|c|c|}
\hline \multirow[t]{2}{*}{ Phosphorus levels } & \multicolumn{3}{|c|}{ Planting geometry } & \multirow[t]{2}{*}{ Mean } \\
\hline & $\begin{array}{l}10 \mathrm{~cm} \mathrm{x} \\
20 \mathrm{~cm}\end{array}$ & $\begin{array}{l}15 \mathrm{~cm} \mathrm{x} \\
20 \mathrm{~cm}\end{array}$ & $\begin{array}{l}20 \mathrm{~cm} \mathrm{x} \\
20 \mathrm{~cm}\end{array}$ & \\
\hline Control & $3.1 \mathrm{~g}$ & $3.3 \mathrm{ef}$ & $3.0 \mathrm{~g}$ & $3.1 \mathrm{c}$ \\
\hline Recommended dose & $3.4 \mathrm{de}$ & $3.5 \mathrm{~cd}$ & $3.2 \mathrm{fg}$ & $3.3 \mathrm{~b}$ \\
\hline $125 \% \mathrm{P}$ of RD & $3.7 \mathrm{bc}$ & $3.8 \mathrm{ab}$ & $3.4 \mathrm{de}$ & $3.6 \mathrm{a}$ \\
\hline $150 \% \mathrm{P}$ of $\mathrm{RD}$ & $3.7 \mathrm{bc}$ & $4.0 \mathrm{a}$ & $3.5 \mathrm{~cd}$ & $3.7 \mathrm{a}$ \\
\hline Mean & $3.5 \mathrm{~b}$ & $3.6 \mathrm{a}$ & $3.3 \mathrm{c}$ & \\
\hline
\end{tabular}

\section{Bulb mass (gm)}

Data about bulb mass (Table 4) showed a remarkable positive response with increasing doses of phosphorus. Treatment receiving phosphorus@150\% of RD recorded the highest bulb mass $(25.6 \mathrm{gm})$ followed by $125 \% \mathrm{P}$ of $\mathrm{RD}$ producing bulb mass of $25.3 \mathrm{gm}$. The results also reflected that planting geometry of $15 \mathrm{~cm} \mathrm{x}$ $20 \mathrm{~cm}$ produced more bulb mass $25.4 \mathrm{gm}$. Interaction of phosphorus levels and planting geometry revealed that phosphorus applied @ 125\% and 150\% of RD documented highest bulb mass i.e. $26.1 \mathrm{gm}$ with planting geometry of $15 \mathrm{~cm} \times 20 \mathrm{~cm}$ which was at par with phosphorus@150\% of RD and planting geometry of $10 \mathrm{~cm} \times 20 \mathrm{~cm}$ producing the bulb mass $25.2 \mathrm{gm}$. Phosphorus governs the several metabolic pathways, enzymatic activities and development of reproductive organs (Sharif et al., 2014). Similarly, Pandey et al. (2012) stated that N (120), P (80) and K (60) $\mathrm{kg} \mathrm{ha}{ }^{-1}$ was a best combination in improving the length of leaves and bulb mass of garlic. Phosphorus increment in fenugreek significantly improved the yield attributes (Nehara et al., 2006).

Table 4: Interactive influence of phosphorus and planting geometry on bulb mass (gm) of garlic.

\begin{tabular}{lllll} 
Phosphorus levels & \multicolumn{3}{c}{ Planting geometry } & Mean \\
& $10 \mathrm{~cm}$ x & $\mathbf{1 5 c m}$ x & $\mathbf{2 0 c m ~ x ~}$ & \\
& $20 \mathrm{~cm}$ & $20 \mathrm{~cm}$ & $\mathbf{2 0 c m}$ & \\
Control & $23.5 \mathrm{f}$ & $24.2 \mathrm{de}$ & $22.9 \mathrm{~g}$ & $23.5 \mathrm{~d}$ \\
Recommended dose & $24.4 \mathrm{~d}$ & $25.2 \mathrm{bc}$ & $23.9 \mathrm{ef}$ & $24.5 \mathrm{c}$ \\
$125 \%$ P of RD & $25.5 \mathrm{~b}$ & $26.1 \mathrm{a}$ & $24.2 \mathrm{de}$ & $25.3 \mathrm{~b}$ \\
$150 \%$ P of RD & $25.7 \mathrm{ab}$ & $26.1 \mathrm{a}$ & $25.0 \mathrm{c}$ & $25.6 \mathrm{a}$ \\
Mean & $24.8 \mathrm{~b}$ & $25.4 \mathrm{a}$ & $24.0 \mathrm{c}$ &
\end{tabular}

LSD for planting geometry: 0.2618; LSD for phosphorus levels: 0.3000; LSD for interaction: 0.5196 .

Table 5: Interactive influence of phosphorus and planting geometry on cloves bulb-1 of garlic.

\begin{tabular}{|c|c|c|c|c|}
\hline \multirow[t]{2}{*}{ Phosphorus levels } & \multicolumn{3}{|c|}{ Planting geometry } & \multirow[t]{2}{*}{ Mean } \\
\hline & $\begin{array}{l}10 \mathrm{~cm} \mathrm{x} \\
20 \mathrm{~cm}\end{array}$ & $\begin{array}{l}15 \mathrm{~cm} \mathrm{x} \\
20 \mathrm{~cm}\end{array}$ & $\begin{array}{l}20 \mathrm{~cm} \mathrm{x} \\
20 \mathrm{~cm}\end{array}$ & \\
\hline Control & $25.0 \mathrm{~g}$ & $25.6 \mathrm{fg}$ & $24.2 \mathrm{~h}$ & $24.9 \mathrm{c}$ \\
\hline Recommended dose & 25.9 ef & $26.7 \mathrm{~cd}$ & $25.3 \mathrm{fg}$ & $26.0 \mathrm{~b}$ \\
\hline $125 \% \mathrm{P}$ of $\mathrm{RD}$ & $26.9 \mathrm{bcd}$ & $27.6 \mathrm{a}$ & $25.5 \mathrm{fg}$ & $26.7 \mathrm{a}$ \\
\hline $150 \% \mathrm{P}$ of $\mathrm{RD}$ & $27.2 \mathrm{abc}$ & $27.5 \mathrm{ab}$ & 26.4 de & $27.0 \mathrm{a}$ \\
\hline Mean & $26.2 \mathrm{~b}$ & $26.8 \mathrm{a}$ & $25.3 c$ & \\
\hline
\end{tabular}

Number of cloves bulb-1

Data in Table 5, showed substantial differences among the phosphorus levels and planting geometry for number of cloves bulb ${ }^{-1}$. Phosphorus @ 150 and $125 \%$ of $\mathrm{RD}$ were the most effective doses in number of cloves (27.0 and 26.7 bulb $^{-1}$ respectively) and the lowest mean value of cloves $\left(24.9\right.$ bulb $\left.^{-1}\right)$ was divulged in control. With respect to planting geometry, $15 \mathrm{~cm}$ x $20 \mathrm{~cm}$ has better effect on number of cloves bulb1 (26.8) as compared to $10 \mathrm{~cm} \times 20 \mathrm{~cm}$ (26.2 cloves bulb $^{-1}$ ) and $20 \mathrm{~cm} \times 20 \mathrm{~cm}$ (25.3 cloves bulb $\left.{ }^{-1}\right)$ of planting geometry. Interaction of phosphorus levels and planting geometry indicated that highest cloves 
bulb $^{-1}$ (27.6) was produced with phosphorus used @ $125 \%$ of RD followed by phosphorus @ 150\% of RD (27.5) with planting geometry of $15 \mathrm{~cm} \times 20 \mathrm{~cm}$ and minimum number of cloves was produced in control with planting geometry of $15 \mathrm{~cm}$ x $20 \mathrm{~cm}(24.2$ cloves bulb $^{-1}$ ). Our results buttressed those of Mulatu et al. (2014) they observed a significant increase in bulb yield with use of $\mathrm{N}$ at rate of 100 and phosphorus at rate of $50 \mathrm{~kg} \mathrm{ha}{ }^{-1}$. Ahmadi and Rohaninezhad (2005) also described an increase in number of cloves through reducing inter-row spacing.

Table 6: Interactive influence of phosphorus and planting geometry on bulb yield ( $M g$ ba $\left.{ }^{-1}\right)$ of garlic.

\begin{tabular}{lllll} 
Phosphorus levels & \multicolumn{3}{l}{ Planting geometry } & Mean \\
& $10 \mathrm{~cm} \mathrm{x}$ & $15 \mathrm{~cm} \times$ & $20 \mathrm{~cm} \mathrm{x}$ & \\
& $20 \mathrm{~cm}$ & $20 \mathrm{~cm}$ & $20 \mathrm{~cm}$ & \\
Control & $3.3 \mathrm{f}$ & $3.5 \mathrm{e}$ & $2.8 \mathrm{~g}$ & $3.2 \mathrm{c}$ \\
Recommended dose & $5.1 \mathrm{c}$ & $5.7 \mathrm{~b}$ & $4.7 \mathrm{~d}$ & $5.2 \mathrm{~b}$ \\
$125 \%$ P of RD & $5.8 \mathrm{~b}$ & $6.5 \mathrm{a}$ & $5.7 \mathrm{~b}$ & $6.0 \mathrm{a}$ \\
$150 \%$ P of RD & $5.8 \mathrm{~b}$ & $6.6 \mathrm{a}$ & $5.7 \mathrm{~b}$ & $6.0 \mathrm{a}$ \\
Mean & $5.0 \mathrm{~b}$ & $5.6 \mathrm{a}$ & $4.7 \mathrm{c}$ &
\end{tabular}

LSD for planting geometry:0.1016; LSD for phosphorus levels: 0.1039; LSD for interaction: 0.1800

Bulb yield ( $M g$ h $\left.a^{-1}\right)$

Bulb yield also had positive response for phosphorus fertilization and planting geometry (Table 6). The result displayed that phosphorus @ 150\% of RD produced highest bulb yield $\left(6.0 \mathrm{Mg} \mathrm{ha}^{-1}\right)$ nonsignificant with $125 \% \mathrm{P}$ of RD $\left(6.0 \mathrm{Mg} \mathrm{ha}^{-1}\right)$ and control produced the lowest bulb yield (3.2 $\left.\mathrm{Mg} \mathrm{ha}^{-1}\right)$. Planting geometry of $15 \mathrm{~cm} \times 20 \mathrm{~cm}$ produced maximum bulb yield $(5.6$ $\mathrm{Mg} \mathrm{ha}{ }^{-1}$ ) significantly different from $10 \mathrm{~cm} \times 20 \mathrm{~cm}$ and $10 \mathrm{~cm} \times 20 \mathrm{~cm}$ of planting distance. The interactive effect of phosphorus and planting geometry exhibited that phosphorus@150\% of RD with planting geometry of $15 \mathrm{~cm} \times 20 \mathrm{~cm}$ recorded the highest value of bulb yield (6.6 $\left.\mathrm{Mg} \mathrm{ha}^{-1}\right)$ statistically similar to $\mathrm{P}$ @ $125 \%$ of RD with planting geometry of $15 \mathrm{~cm} \mathrm{x}$ $20 \mathrm{~cm}\left(6.5 \mathrm{Mg} \mathrm{ha}^{-1}\right)$. The improved bulb yield at a closer spacing in planting geometry of $15 \mathrm{~cm} \times 20 \mathrm{~cm}$ might be explained with increased planting density/ unit area. Whereas, the low bulb yield in $20 \mathrm{~cm} \mathrm{x}$ $20 \mathrm{~cm}$ spacing could be correlated with reduced plant population in this treatment. Moreover, the total yield depends not only on the individual plant performance but also on plant population per unit area as depicted in our study. Our results are supported by findings of many researchers that sustainable production of garlic responded positively to intra-row spacing (Karaye and Yakubu, 2006; Ademe et al., 2012; Hamma et al., 2013). Compatible results have also been observed by Bhunia et al. (2006) that increasing doses of phosphorus improved the yield characteristics of different crops.

Table 7: Effect of phosphorus and planting geometry on net income and benefit: cost ratio (BCR) of the garlic crop.

Phosphorus levels

Recommended dose

$125 \% \mathrm{P}$ of RD

$150 \% \mathrm{P}$ of $\mathrm{RD}$

$\begin{array}{ll} & 15 \mathrm{~cm} \times 2 \mathbf{c m} \\ & \text { Cost of production (Rs.) } \\ \text { Control } & 60000 \\ \text { Recommended dose } & 65000 \\ 125 \% \text { P of RD } & 70000 \\ 150 \% \text { P of RD } & 73000 \\ & 20 \mathrm{~cm} \times 20 \mathrm{~cm} \\ & \text { Cost of production (Rs.) } \\ \text { Control } & 60000 \\ \text { Recommended dose } & 65000 \\ 125 \% \text { P of RD } & 70000 \\ 150 \% \text { P of RD } & 73000\end{array}$

$10 \mathrm{~cm} \times 20 \mathrm{~cm}$

Cost of production (Rs.)

60000

65000

70000

73000

\section{Planting geometry}

Gross income (Rs.)

166835

256335

290165

294000

Gross income (Rs.)

179000

287500

328500

333500

Gross income (Rs.)

143000

239835

287665

287335

Net income (Rs.)
106835
191335
220165
221000

Benefit: Cost

2.780583

3.943615

4.145214

4.027397

Net income (Rs.)

Benefit: Cost

2.983333

4.423077

4.692857

4.568493

222500

258500

260500

Benefit: Cost

2.383333

3.689769

4.1095

3.936096

December 2020 | Volume 33 | Issue 4 | Page 696 
Economic analysis

According to Khan et al. (2012) economic viability of any cropping technology has a prime importance for its acceptance among the farming community. An economic analysis was assessed to determine the best, optimum and economical phosphorus level and planting geometry to cultivate garlic under saltaffected conditions (Table 7). Economic analysis showed that maximum net income was achieved with phosphorus@125\% of RD with planting geometry of $15 \mathrm{~cm} \times 20 \mathrm{~cm}$ (Rs. $258500 \mathrm{ha}^{-1}$ ). Increased yield with planting geometry of $15 \mathrm{~cm} \times 20 \mathrm{~cm}$ and P @ $125 \%$ of RD as compared to planting geometry of $20 \mathrm{~cm} \times 20 \mathrm{~cm}$ could be attributed to increased plant density and more bulb yield per land unit area. Our findings are plausible with Doro (2012) they found that all yield characters assessed decreased when row spacing increased from 5 to $20 \mathrm{~cm}$ in garlic.

\section{Conclusions and Recommendations}

Findings of the present work showed that tallest plant, more leaves plant ${ }^{-1}$, maximum bulb diameter and mass, cloves bulb ${ }^{-1}$ and superior bulb yield were found with phosphorus @ 150\% and 125\% of RD with planting geometry of $15 \mathrm{~cm} \times 20 \mathrm{~cm}$. However, in terms of economic return and yield of garlic, the treatment with phosphorus @ 125\% of RD with planting geometry of $15 \mathrm{~cm} \times 20 \mathrm{~cm}$ proved superior with high net income (Rs. 258500) and cost benefit ratio (4.69) than all other treatments.

\section{Novelty Statement}

A huge gap exists between actual and yield potential of existing crops due to inadequate supply of inputs, lack of comprehensive production technologies and non-judicious use of fertilizers. So, it is imperative to reassess the fertilizers rate for sustainable crop productivity under a salinized environment. Use of phosphorus@125\% of RD with planting geometry $15 \mathrm{~cm} \times 20 \mathrm{~cm}$ is proposed as a most cost-effective management practice for garlic cultivation.

\section{Author's Contribution}

Muhammad Qaisar Nawaz, conceived the idea, conducted the study for three years and wrote the article, Khalil Ahmed, Ghulam Qadir, wrote abstract and materials and methods, Amar Iqbal Saqib, Muhammad Rizwan, Muhammad Faisal Nawaz, did data collection and statistical analysis, Imtiaz Ahmad Warraich, provided technical input at every step.

\section{Conflict of interest}

The authors have declared no conflict of interest.

\section{References}

Abubaker, S., 2008. Effect of plant density on flowering date, yield and quality attribute of bush beans (Phaseolus Vulgaris L.) under center pivot irrigation system. Am. J. Agric. Biol., Sci., 3(4): 666-668. https://doi.org/10.3844/ ajabssp.2008.666.668

Ademe, D., D. Belew and G. Tabor. 2012. Influence of bulb topping and intra row spacing on yield and quality of some shallot (Allium Cepa Var. Aggregatum) varieties at Aneded woreda, western Amhara. Afr. J. Plant Sci., 6(6): 190202. https://doi.org/10.5897/AJPS11.298

Ahmadi, H.A. and H. Rohaninezhad. 2005. Effects of inter and intra-row spacing on yield and yield components of garlic (cv. Mazand). Iran. Hortic. Sci. Cong., pp. 333-334.

Alam, M.M., M.H. Ali, A.K.M.R. Amin and M. Hasanuzzaman. 2009. Yield attributes, yield and harvest index of three irrigated rice varieties under different levels of phosphorus. Adv. Biol. Res., 3(3-4): 132-139.

Ananthi, T., M.M. Amanullah and K.S. Subramanian. 2010. Influence of mycorrhizal and synthetic fertilizers on soil nutrient status and uptake in hybrid maize. Madras Agric. J., 97 (10-12): 374-378.

Awad, A.S., D.G. and Edwards, L.C. Campbell. 1990. Phosphorus enhancement of salt tolerance of tomato. Crop Sci., 30: 119-123. https://doi.org/10.2135/ cropsci1990.0011183X003000010028x

Bhattacharyya, P. and R.K. Jain. 2000. Phosphorus solubilizing biofertilizers in the whirlpool of rock phosphate-challenges and opportunities. Fertl. News, 45: 45-51.

Bhunia, S. R., R.P.S. Chauhan, B.S. Yadav and A.S. Bhati. 2006. Effect of phosphorus, irrigation and Rhizobium on productivity, water use and nutrient uptake in fenugreek (Trigonella foenum-graecum). Ind.J. Agron., 51(3): 239-241.

Blackshaw, R.E., R.N. Brandt, H.H. Janzen and T. Entz. 2004. Weed species response to phosphorus fertilization. Weed Sci., 52: 406- 
412. https://doi.org/10.1614/WS-03-122R

Bodnar, J.L., B. Schumacher and S. Uyenaka. 1998. Garlic production in Ontario. omafra factsheet, Canada, pp.1-8.

Castellanos, J.Z., J.L. Ojodeagua, F. Méndez, S. Villalobos-Reyes, V. Badillo, P. Vargas and I. Lazcano. 2001. Phosphorus requirements by garlic under fertigation. Better Crops Int., 15(2): 21-23.

Dayi, R.U., 2008. Effects of NPK fertilizer and intra row spacing on the growth and yield of garlic (Allium sativum L.). Paper Presented during the Second National Conference of the Joint CST of Hassan Usman Katsina Polytechnic 27-30 ${ }^{\text {th }}$ November,

Dhanushkodi, V. and K. Subrahmaniyan. 2012. Soil Management to Increase Rice Yield in Salt affected Coastal Soil. 2012. A Review. Int. J. Res. Chem. Environ., 2 (4): 1-5.

Doro, A.K., 2012. Response of garlic (Allium sativum L.) to intra-row spacing at ajiwa irrigation site of katsina state Nigeria. Jorind, 10(2): 103-107.

Gebrehaweria, T., 2007. Effects of mulching, nitrogen and phosphorus on yield and yield components of garlic (Allium sativum L.) at Alshaday, eastern zone of Tigray, northern Ethiopia. M.Sc. thesis, Haramaya University, Ethiopia.

Getachew, T. and A. Zellek. 2000. Achievements in shallot and research. Report. No. 36 Ethiop. Agric. Res. Organ., Addis Ababa, Ethiopia.

Government of Pakistan. 2012. Agriculture statistics of Pakistan, Ministry of food and agriculture Islamabad.

Hamma I.L., U. Ibrahim and A.B. Mohammed. 2013. Growth, yield and economic performance of garlic (Allium satioum L.) as influenced by farm yard manure and spacing in Zaria, Nigeria. J. Agric. Econ. Dev., 2(1): 1-5.

Hore, J.K., S. Ghanti and M. Chanchan. 2014. Influence of nitrogen and sulphur nutrition on growth and yield of garlic (Allium satioum L.). J. Crop Weed, 10(2): 14-18.

Hussen, S., F. Medhin and A. Tadesse. 2014. Effect of intra-row spacing on growth performance of garlic (Allium sativum L.) at the experimental site of Wollo University, south wollo, ethiopia. Eur. J. Agric. For. Res., 2(4): 54-61.

Jat, B.L. and M.S. Shaktawat. 2001. Effect of phosphorus, sulphur and biofertilizers on yield attributes and yield of fenugreek (Trigonella foenum-graecum L.) and their residual effect on pearl millet (Pennisetum gluacum). Ind. J. Agron., 46 (4): 627-634.

Karaye, A.K. and A.I. Yakubu. 2006. Influence of intra-row spacing and mulching on weed growth and bulb yield of garlic (Allium sativum L.) in Sokoto, Nigeria. Afr. J. Biotech., 5(3): 260-264.

Khan, G.S., 1998. Soil salinity/sodicity status in Pakistan. Soil Survey of Pakistan, Lahore. pp. 39.

Khan, M.B., M. Khan, M. Hussain, M. Farooq, K. Jabran and D.J. Lee. 2012. Bio-economic assessment of different wheat-canola intercropping systems. Int. J. Agric. Biol., 14: 769774.

Khiriya, K.D., R.S, Sheoran and B.P. Singh. 2001. Growth analysis of fenugreek (Trigonella foenum-graecum L.) under various levels of farmyard manure and phosphorus. J. Spices Aromat. Crops, 10(2): 105-110.

Kilgori, M.J., M.D. Magaji and A.I. Yakubu. 2007. Effect of plant spacing and date of planting on yield of two garlic (Allium Satioum L.) cultivar in sokoto, Nigeria. Am. Eur. J. Agric. Environ. Sci., 2(2): 153-157.

Mohammad, R.A. and M.J. Arshadi. 2012. Effect of planting date and plant density on yield and yield components of garlic in fariman. Adv. Environ. Biol., 6(3): 583-586.

Mulatu, A., B. Tesfaye and E. Getachew. 2014. Growth and bulb yield garlic varieties affected by nitrogen and phosphorus application at mesqan woreda, south central Ethiopia. Sky J. Agric. Res., 3(11): 249-255.

Naruka, I.S. and B.S. Dhaka. 2001. Effect of row spacing and nitrogen fertilization on growth, yield and composition of bulb in garlic (Allium satioum L.). Cultivars J. Spice Aromat. Crops, 10(2): 44-48.

Nehara, K.C., P.D. Kumawat and B.P. Singh. 2006. Response of fenugreek (Trigonella foenumgraecum L.) to phosphorus, sulphur and plantgrowth regulators under semi-arid eastern plains zone of Rajasthan. Ind. J. Agron., 51(1): 73-76.

Pandey, V.K., S. Kumar and Y.C. Yadav. 2012. Effect of nitrogen, phosphorus and potash on growth, yield and yield attributing traits in garlic (Allium satioum L.) cv. Agrifound White. 
Int. J. Plant Sci., 7(1): 71-73.

Tuncurk, R., 2011. The effects of varying row spacing and phosphorus doses on the yield and quality of fenugreek (Trigonella foenum-graecum L.). Turk. J. Field Crops, 16(2): 142-148.

Sankaran, N., S. Meena and N. Sakthivel. 2005. Input management in maize. Madras Agric. J., 92(7-9): 464-468.

Shah, M.A., A. Manaf, M. Hussain, S. Farooq and M. Zafar-ul-Hye. 2013. Sulphur fertilization improves the sesame productivity and economic returns under rainfed conditions. Int. J. Agric. Biol., 15: 1301-1306.

Sharif, M., M. Arif, T. Burni, F. Khan, B. Jan and I. Khan. 2014. Growth and phosphorus uptake of sorghum plants in salt affected soil as affected by organic materials composted with rock phosphate. Pak. J. Bot., 46(1): 173-180.
Sobia, N., Irum raza, M.A. Masood, M.Z. Anwar and N. Habib. 2014. Forecasting of garlic area and production in Pakistan. Sci. Tech. Dev., 33 (3): 123-126.

Steel, R.G.D., J.H. Torrie and D.A. Dickey. 1997. Principles and Procedures of Statistic: A Biometrical Approach. $3^{\text {rd }}$ edition, Mc Graw Hill book Co. Inc. New York. pp. 400428.

Yusuf,M.,S.A.Hasan,B.Ali,S.Hayat,Q.Fariduddin and A. Ahmad. 2008. Effect of salicylic acid on salinity-induced changes in Brassica juncea. J. Integr. Plant Boil., 50: 1096-1102. https://doi. org/10.1111/j.1744-7909.2008.00697.x

Zhang, Q, K. and Rue. 2012. Glycinebetaine seed priming improved osmotic and salinity tolerance in turf grasses. Hortic. Sci., 47: 1171-1174. https://doi.org/10.21273/ 